Tolerance in critical and political theory: co-existence or parts of something bigger?

Our interest in this Critical Exchange is to comment on tolerance, as one among other candidate concepts, for what it can bring towards struggles for equality and respect, and towards understanding those aspects of our societies that make such struggles promising and problematic. More precisely, we wish to address a disjuncture that concerns us in our work on Muslim politics in Europe: between socio-political effects that are said to ensue where tolerance is deployed as a regulatory device and the possibilities tolerance contains for subjects that are engaged in political struggles. For the purpose of our discussion here, and notwithstanding immense variety within these categories, we address this disjuncture as one between critical and political theories, that is, between approaches that predominantly aim at historical meanings and socio-political effects of tolerance and others that specify its normative potentials.

Rather than attempting to bridge the two orientations, we bring some of the circumstances of Muslim politics into view and ask if they throw a light on the disjuncture that alleviates some of its tensions. This entails questioning how tolerance may become a resource in

political mobilizations that (speaking to our area of interest) come from within the multiplicity of Muslim claims for inclusion, difference or respect; or why it can't. Limitations of tolerance, we conclude, owe less to repressive potentials inherent in it and more to difficulties imagining democratic and dialogical politics within its confines.

\title{
Two perspectives
}

In negotiations of the place of Muslims in Europe, and as a consequence of the resultant encounters, not just tolerance, but also liberalism and secularism, have been opened up in unexpected ways, expanded and pluralized and become subject to various attempts at forcing 
retrenchment. Despite the false unity that posing the 'Muslim question' in the singular implies, what is shared among its instantiations is that they have become a primary occasion for defining the meaning and scope of tolerance.

The figure of the archaic Muslim, scheming to impose controls over liberal society that roll back hard-fought freedoms, represents an influential illustration for contemporary intolerance. Where actual Muslims struggle for equality and respect, they not least face up to the misrecognition that this archetype represents. In this situation, the dilemma of tolerance as a category for political claims is its evident implication in producing the injustices that claimants seek to address.

Attending to this dilemma, we are led down two contradictory paths. Tolerance is undoubtedly a core element in how liberal states conceive of their own position towards ethnocultural-religious 'difference'; it is an important element of national identity-building and civilizational self-assurance. Examining this role, critical theorists identify socio-political effects where states engage 'difference' in order to regulate its manifestations. As Talal Asad (2003, p. 8) has it, the liberal state 'does not guarantee tolerance [but] puts into play different structures of ambition and fear'. This would seem confirmed by the way tolerance features as a distinctive achievement that has to be defined and solidified against illiberal Others - an issue we will return to below. Genealogies of tolerance that attend to these political functions usually do not supply normative evaluations of the type of order that liberal tolerance reflects, the practices it supports or of how they could be improved. They suggest that tolerance should be subjected to a critical view that glimpses behind the veneer of liberal universality. 
Yet a multiplicity of struggles for equality and respect point to the need for a different perspective. Regarding political claims for decency or descriptions of conviviality in conditions of deep diversity, situations present themselves that direct us towards different points of view. The practices and demands that this second perspective attempts to capture would be devalued if they were reduced to regulatory effects and treated as mere genealogical artefacts. The experiences that lead actors to denounce injustices they experience as 'intolerance' would not be fully understood or adequately described in this first mode. This does not imply that tolerance is always an adequate descriptor for the concerned practices and demands (and certainly not that critical genealogies of tolerance have no case); it introduces socio-political practice as an important dimension for considering how our normative and critical vocabulary ought to be structured.

\section{Making use of tolerance}

Beyond analysing its top-down functions and regulatory effects, the focus on political agency means of course expressing some type of 'positive' interest in the normative potentials of tolerance. Before attending to the former in more detail, we wish to further unpack these potentials by introducing two conditions according to which we may wish to evaluate potentials of tolerance: its ability to challenge the marginalisation that individuals or groups experience; and its ability to not just describe, but also support, political struggles. The first refers to the scope of our normative concepts and what objectives are possible or impossible to conceive with the concepts we choose to employ. If it turns out that significant inequalities are outside the purview of our chosen conceptual framework, we may choose to either expand or abandon it.

We will later return to these criteria for thinking about the political usefulness of tolerance. As suggested, this usefulness has been cast into doubt. Wendy Brown (2006, p. 36) 
argues that tolerance is implicated in the state's regulatory operations. Its function is 'to contain potential crises ... that threaten to reveal the shallow reach of liberal equality and the partiality of liberal universality'. It is a device in the management of Others and for the channelling of liberal 'aversion'. For the liberal state, deploying the concept 'sanction[s] illiberal aggression toward what is marked as intolerable without tarring the "civilized" status of the aggressor' (2006, p. 179). Reworking liberalism, in order to make it 'more modest, more restrained in its imperial and colonial impulses' (2006, p. 175) would be desirable, but it is uncertain what remains of tolerance, given its culturalist or neoliberal baggage, after this work has been done.

The critical challenge has to be taken seriously but it also ought to be examined itself with a view to potentials and possibilities, and with an interest in how - without reducing one into the other - normative frames and genealogical interests may become mutually informative. The best analytical-political framework is one which both identifies and critiques the negative while elaborating the positive in what exists or could be struggling to exist. In relation to the latter, it is part of the analyst's job to show that what could exist is an intellectually coherent idea; is worthwhile as a goal in relation to or in combination with other possible, contending goals; and is a contextualised, real possibility (see Dobbernack and Modood, 2013).

Tolerance, we agree with critical theorists, is implicated in the political ordering of difference both historically and today. It has been employed as a historical master-narrative and continues to play a particular role in definitions of national identity today. The British Prime Minister argues that to achieve 'stronger societies and stronger identities', it has become necessary to be 'unambiguous and hard-nosed about this defence of our liberty', whilst 'handsoff tolerance has only served to reinforce the sense that not enough is shared'. Previous manifestations of tolerance have led to moral indecisiveness, and tolerance needs to become 
more active, aggressive and hands-on. In the attempt to delineate a German Leitkultur, toleration features as a distinctive achievement of either the Enlightenment or a 'Judeo-Christian heritage'. Angela Merkel's contribution to the Leitkultur debate is to ask for 'a clear commitment to the nation (Nation und Vaterland), to an open-minded patriotism, to tolerance and to moral courage'. Commenting on the Swiss referendum on minarets, Sarkozy suggested that while France was a 'country of tolerance and respect', it also 'had to be respected'. The republic is a space of tolerance, yet respect towards republican norms ought to delimit the visibility of religion in public spaces, by cultural assimilation, if possible, and by law, if necessary.

Tolerance plays a role in the definition of a national self within a 'civilizational frame'. In this form and others, it enshrines a new conditionality of acceptance upon public endorsement of a number of liberal, republican or secular tenets, which are always construed in a way that favours some and is biased against others. The domain of intolerable difference is more rigidly demarcated and national identities defined in opposition to antagonistic Others that cannot be tolerated. Today, the marginalization of Muslim minority groups in Western Europe is worsened and justified with reference to putatively liberal arguments, making it appropriate to speak of distinctively liberal formations of intolerance. But the value of tolerance in political struggles may not be determined by the meaning it thus obtains. Its role in political claims-making and its usefulness for how marginalized groups may appeal to standards of decency may be affected, but we don't believe that possibilities will be foreclosed completely. This is most importantly the case as the meaning of the concept can be contested and its deployment will be difficult to predict. 


\section{Demanding tolerance from below}

In one of many examples of anxiety about the Muslim presence, a group of educationalists has recently been accused of fostering 'extremism' at some schools in various neighbourhoods of Birmingham, UK. Although most of the claims were revealed as overblown or false, accusations did not collapse but were shifted from the domain of 'promoting extremism' to 'failing to promote British values', in particular failing to promote 'tolerance and harmony between different cultures'. The sticking point became that 'children are not being encouraged to develop tolerant attitudes towards all faiths and all cultures'.

The riposte by educationalists, the concerned school trusts and Muslim associations was to remind their accusers that faith-based and community-run education constituted a governmental objective that was meant to be extended. Whatever one thinks of religious conservatism and its place in education, the same entitlements and standards that apply to other faiths should apply to Muslims, too. Against an alliance of secularists and neo-conservatives of considerable hostility towards Islam, aided by a considerable lack of understanding in the mainstream, the request was for religious 'tolerance', appropriately understood, and against the way in which the alleged failure to 'promote tolerance' was deployed as a stigmatizing device.

The case, exemplary for many controversies, might prompt us towards a strong critique of the Islamophobic racism that is present not just in British public life and the institutional biases it underpins. But it should also make us attend to the arguments that were actually deployed to resist such stigmas and in the role that requests for decency and fairness, framed in the language of tolerance, might play where actors attempt to do so. Merely utilising or critiquing dominant discourses of tolerance is inadequate to empower the marginalised. 


\section{$\underline{\text { Having it all }}$}

Can we have a position, then, that is critical and constructive: that takes notice of, but does not turn regulatory effects into absolutes, at least not at the expense of political and interpretive struggles over the nature and meaning of tolerance? This would be a position that does not just problematize but can articulate and develop further the normative understandings expressed in institutions, by engaging citizens, and among oppositional movements.

A number of perspectives present themselves. Philosophical hermeneutics envisages a double disposition of suspicion and understanding. Tolerance itself could be understood as a relational attitude that follows this orientation as it conjoins 'components' of suspicion and respect. But also the non-engaged perspective of the observer may benefit from a combination of critical and constructive faculties, in particular where we examine the operations that political actors perform in making claims for tolerance by deploying existing terms, but usually also by interpreting and modifying the meaning of tolerance to fit their requests. A multiculturalist version of this kind of approach is the use of intercultural dialogue to resolve controversies such as in relation to Muslim anger over offensive portayals, which starts with existing 'operative public values' but aims to modify them in the light of new minority vulnerabilities to which those values may be insensitive (Parekh, 2000).

Other contributions, such as from within the 'sociology of critical practice', make the more general point that the social world should be seen not as 'the site of domination endured passively and unconsciously, but instead as a space shot through by a multiplicity of disputes, critiques, disagreements' (Boltanski, 2011, p. 27). Tolerance plays a role in structuring relations, constituting norms of evaluation or conduct, and regulating 'difference'. But this role does not exhaust its potentials in social and political practice. Even within governmental apparatuses, we 
may require a viewpoint akin to the image of 'street-level bureaucrats' who not simply discharge, but re-interpret, modify or circumvent governmental objectives. In our mind, the most relevant question about tolerance from within this orientation would be to ask how it corresponds with the 'critical practices' that individuals, in particular those that request tolerance for themselves and for others, are engaged in. At a general level, we suspect that the most plausible response would be to say that the pre-fabricated meaning of liberal tolerance will have some consequences for political practice. By posing the question of how much and what kind we are already led to the sorts of issues that we think are significant to explore in descriptions of political agency.

In the remainder, we wish to merely offer some comments that reach across both perspectives, are relevant for our case and refer back to the two conditions mentioned earlier: that concepts show some correspondence to significant injustices experienced and allow for political mobilization.

\section{$\underline{\text { Back to agency }}$}

In the European condition of contested multiculturalism, tolerance is likely to be an important category of political practice where claims are put forward for minimal decency and against the experience of oppressive constraints. Where minority groups face the latter, as in the Birmingham case, tolerance may be a tool in their arsenal that allows appealing to standards of conduct that liberal states usually publicly profess. If claims become more expansive and demanding, the normative vocabulary tends to shift beyond tolerance's conceptual confines. It is in these cases, that the request to be tolerated or the renunciation of intolerance may appear insufficient and insecure or where the continued disapproval that tolerance implies is found to be insulting. 
It is here, too, that multicultural political practice, observable in many different shapes, suggests that tolerance is not good enough. This is not because the concept is invariably tainted, but because there is little correspondence - descriptively, from the outside, and for struggling agents and the tendency of their politics - with requests for more complete forms of equality. We suggest that this lack of correspondence with multicultural repertories matters not just in its own right but in a way that puts the disjuncture we are concerned with into place.

A central feature of claims for equality that exceed tolerance is that they request a status that is not passively filled out but actively inhabited. For recognition, it is not the conferral of pre-fabricated esteem that matters but the negotiation of the terms of recognition, understood as 'games of reciprocal disclosure and acknowledgment' (Tully, 2000, p. 479). The same is the case for multicultural citizenship, understood as a work-in-progress, as only ever partly constituted and extended by contestations and novel demands for due recognition as circumstances shift. This implies an understanding of citizenship as conversation and renegotiation: not just about who is to be recognized but about what recognition is and about the terms of citizenship itself (Modood, 2007). The claim here is for having a say in what it means to be a citizen.

We accept the point made by Forst (2007, p. 236-237) and others that these situations presuppose prior recognition, namely the internal recognition of a collective identity without which group-based mobilizations are impossible to achieve. But the consequence is not that recognition ceases to be an important request (although the many understandings of recognition make such assertions difficult); it is rather that the type of recognition that is sought tends to reflect other important standards, not least justice, respect and reciprocity. The injustice entailed in (external) misrecognition, which often constitutes the starting point for political struggle, is the irreversibility of the situation it reflects and that nothing can be done about it. Next to 
demands for the state to stay out of internal self-definitions and for the de-stigmatization of public identities, a level playing field that allows for reciprocal forms of identity disclosure constitutes the most important request in today's multicultural politics. Distinguishing more 'demanding' requests - regardless of how we choose to label them - from tolerance, the claim for the co-production of the terms of one's belonging stands out. This is a state of affairs that it is unlikely to ever be fully realized, which does not mean that its absence is not being politically noted by actors that encounter social stigmas of the sort we have mentioned (see Dobbernack, Meer and Modood, 2014).

It can also be a measure for attending to the political potentials of tolerance and its alternatives. The types of tolerance that feature today as a central element in national identity narratives and for civilizational self-assurance, some of which we have sketched out above, do not allow for much co-production. The more 'activist' tolerance that Cameron endorsed with his notion of 'muscular liberalism' exemplifies this. German Leitkultur, with its commitment to a 'civilizational' value of tolerance, did nothing to enhance participation of German Muslims (and was more than anything a device to continue their marginalization). New avenues emerged when some politicians in Germany began stating that 'Islam is a part of Germany', which arguably created a symbolic space, no matter how incomplete, where more equal forms of belonging became imaginable.

These are the circumstances where tolerance, assuming that it describes relations of democratic reciprocity, can and should be separated out from narratives of civilizational supremacy. This is where the potentials of tolerance lie, but also where we realize that these potentials are limited not just because many of its manifestations do reflect regulatory attempts of putting 'difference' in its place. Such limitations are also not just about the 'minimalism' of 
tolerance, as if the problem was a matter of mere scope. They are about the apparent resistance of the category to political practices that aspire towards, or reflect, democratic reciprocity and civic equality.

\section{References}

Asad, T. (2003) Formations of the Secular: Christianity, Islam, Modernity. Stanford, CA: Stanford University Press.

Boltanski, L. (2011) On Critique. A Sociology of Emancipation. Cambridge: Polity Press.

Brown, W. (2006) Regulating Aversion. Tolerance in the Age of Identity and Empire. Princeton, N.J.: Princeton University Press

Dobbernack, J., Meer, N. and Modood, T. (2014) Misrecognition and Political Agency. The Case of Muslim Organisations in a General Election. British Journal of Politics and International Relations (online first).

Dobbernack, J. and Modood, T. (2013) (Eds.) Tolerance, Intolerance and Respect. Hard to Accept? Basingstoke: Palgrave.

Forst, R. (2007) 'To Tolerate Means to Insult'. Toleration, Recognition, and Emancipation, in: Brink, B. van den and Owen, D. (Eds.) Recognition and Power. Axel Honneth and the Tradition of Critical Social Theory. Cambridge: Cambridge University Press, 215-237.

Modood, T. (2007) Multiculturalism: A Civic Idea (Second Edition, 2013). Cambridge: Polity Press.

Parekh, B. (2000) Rethinking Multiculturalism (Second Edition, 2006). Cambridge, Mass: Harvard University Press.

Tully, J. (2000) Struggles over Recognition and Distribution. Constellations 7(4): 469-482. 
Jan Dobbernack

European University Institute, Fiesole, FI 50014, Italy, and University of Lincoln, Lincoln, LN6 7TS, UK

jdobbernack@lincoln.ac.uk

Tariq Modood European University Institute, Fiesole, FI 50014, Italy, and University of Bristol, Bristol, BS8 1TX, UK t.modood@bristol.ac.uk 